Rapid Reviews COVID-19

\title{
Reviews of "Durable SARS- CoV-2 B cell immunity after mild or severe disease"
}

Joel Wilmore ${ }^{1}$, Mark Sangster ${ }^{2}$

${ }^{1}$ Assistant Professor, SUNY Upstate Medical University, Microbiology and Immunology,

${ }^{2}$ University of Rochester Medical Center, Microbiology and Immunology

Published on: Jan 20, 2021

DOI: 10.1162/2e3983f5.562bec2d

License: Creative Commons Attribution 4.0 International License (CC-BY 4.0). 
To read the original manuscript, click the link above.

Summary of Reviews: This study investigates B cell responses in COVID-19 patients and finds infection elicits $S$ protein $R B D$-specific memory $B$ cells in most participants. Reviewers deem the study reliable, but find some claims overreaching citing lack of functional data.

\section{Reviewer 1 (Joel Wilmore)}

Reviewer 2 (Mark Sangster) | प्र०ण

$$
\begin{aligned}
& \text { RR:C19 Strength of Evidence Scale Key. } \\
& \text { प्रमप = Misleading } \\
& \text { प्र००० = Not Informative } \\
& \text { प्रा पि = Potentially Informative }
\end{aligned}
$$

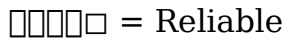

$$
\begin{aligned}
& \text { प्राप्र = Strong }
\end{aligned}
$$

To read the reviews, click the links below. 